
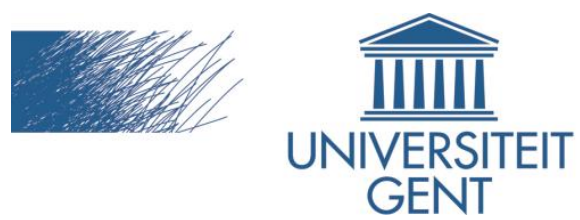

biblio.ugent.be

The UGent Institutional Repository is the electronic archiving and dissemination platform for all UGent research publications. Ghent University has implemented a mandate stipulating that all academic publications of UGent researchers should be deposited and archived in this repository. Except for items where current copyright restrictions apply, these papers are available in Open Access.

This item is the archived peer-reviewed author-version of:

A spatial analysis of multiple airport cities

Derudder, B., Devriendt, L \& Witlox, F.

In: Journal of Transport Geography, 18, 345-353, 2010

doi: 10.1016/j.jtrangeo.2009.09.007

To refer to or to cite this work, please use the citation to the published version:

Derudder, B., Devriendt, L \& Witlox, F. (2010). A spatial analysis of multiple airport cities. Journal of Transport Geography 18, 345-353. doi: 10.1016/j.jtrangeo.2009.09.007 


\title{
A SPATIAL ANALYSIS OF MULTIPLE AIRPORT CITIES
}

\author{
Ben Derudder, Lomme Devriendt, Frank Witlox ${ }^{1}$ \\ Ghent University, SEG Social and Economic Geography, Krijgslaan 281 (S8), 9000 Ghent, \\ Belgium ${ }^{2}$
}

\begin{abstract}
This paper presents a detailed empirical description of airport connectivities in four major multiple airport cities (London, New York, Los Angeles, and San Francisco). Our analysis draws on data derived from a previously largely untapped information source, i.e. the socalled 'Marketing Information Data Transfer' (MIDT). This dataset contains information on actually flown transnational routes, which allows for a thorough assessment of the chief connectivity characteristics of specific airports. Combined with information derived from a number of other sources, our results point to functional divisions among airports, both in terms of their geographical scale (e.g. national, regional, and international airports) and their specific role in the airline network (e.g. origin/destination versus hub airports). The implications of the results are discussed, and some avenues for future research are considered.
\end{abstract}

Keywords: Multiple Airport Cities, Airline network, London, New York, Los Angeles, San Francisco

\footnotetext{
${ }^{1}$ Corresponding author. Tel.: +32 92644556; fax: +32 92644985. E-mail addresses: ben.derudder@ugent.be (B. Derudder), lomme.devriendt@ugent.be (L. Devriendt), frank.witlox@ugent.be (F. Witlox).

${ }^{2}$ http://www.geoweb.ugent.be/seg
} 


\section{INTRODUCTION}

In a deregulated air transport market, airports in multiple airport cities (MACs) only survive by attracting and accommodating enough passengers. A study by Pels et al. (1997), for instance, reveals that an airline's choice for a specific airport is driven by the level of demand more so than by the airport's pricing policies. ${ }^{3}$ To obtain a more refined picture of what constitutes and drives the 'level of demand' at MAC airports, Pels et al. $(2000,2001)$ later engaged in an analysis of the variables influencing the choice for a particular airport in the San Francisco Bay Area. They hereby distinguish between two sets of mutually interacting factors, i.e. (i) airport characteristics and (ii) airline characteristics. The former refer to variables such as access time and passenger charges, the latter to variables such as airline pricing schemes, offered direct destinations, and flight frequencies. To model the impact of these variables (as well as their interactions), Pels et al. $(2000,2001)$ apply a nested multinomial logit model to the airport system in the Bay Area. The data consist of a combination of (i) airport-specific survey information gathered by the Oakland-based Metropolitan Transportation Commission (MTC) and (ii) airline-specific information on direct routes provided by the Official Airline Guide (OAG).

The research by Pels et al. $(2000,2001)$ continues a long tradition of demand modelling for MAC airports (e.g. Kanafani et al., 1975; De Neufville, 1976, 1984; Ashford and Benchemam, 1987; Harvey, 1987; Thompson and Caves, 1993). However, in spite of the sophistication of these models, their relevance seems to be somewhat hampered by a number of conceptual and data deficiencies. Conceptually, it can be noted that airport interactions in a MAC are only partly about competition. Indeed, the very existence of a MAC system also allows airlines to deal with capacity constraints at the premier airport (e.g. London Gatwick as de facto reliever airport for British Airways) or serving specific niches (e.g. London City for British Airways' short-haul business flights). In such cases, it can be said that the connectivity of MAC airports is complementary rather than competitive in nature. This also opens up questions of how this cooperation occurs 'on the ground' (e.g. the transfer system between Heathrow and Gatwick, see http://alturl.com/5ba2, last accessed 8/7/2009). The subtle balance between competition and cooperation in a MAC can clearly be observed in the multi-nodal region centred on the Netherlands, Belgium and northern France. In this region, the Air France/KLM merger has opened up new possibilities for fine-tuning connectivity between Charles de Gaulle and Amsterdam as the companies' networks are largely complementary. At the same time, this merger also has an important ground transportation component to it: fast rail links between Brussels and Antwerp on the one hand and Schiphol and Charles de Gaulle on the other hand have expanded both airports' market area to the degree that the entire region may now be considered as a single large-scale MAC with a subtle balance of competition and cooperation amongst its different airports.

\footnotetext{
${ }^{3}$ Starkie (2002, p. 67), however, points out that the situation may be somewhat different for low-cost carriers. The pricing policy-based competition between Luton and Stansted in the early 1990s is a prime example here: encouraged by the attraction of lower charges Ryanair decided to switch most of its flight from Luton to Stansted.
} 
In terms of data, in turn, a key missing variable in the MAC competition models of Pels et al. $(2000,2001)$ - as the authors themselves acknowledge - is actual ticket prices. The absence of this information leads the authors to second-guessing the impact of low cost-carriers on the model results. More importantly, however, the adopted research design in Pels et al. $(2000,2001)$ equally implies that only a specific portion of the 'level of demand' is modelled: only potential origin passengers are considered. Exclusively modelling the demand of prospective origin passengers in a MAC system is, of course, an entirely valid approach for answering some salient research and policy questions (e.g., the impact of airport accessibility on attracting origin passengers). But this partial approach becomes less suitable if one wishes to consider the total demand level at a MAC airport: destination and hub passengers are dropped off the map. However, competition for hub passengers in particular is becoming increasingly relevant because of the adoption of hub-and-spoke models for organizing route structures (Button, 2002). Once again, the Air France/KLM is instructive in this context, as the company's 15 + daily return flights between Schiphol and Charles de Gaulle are clearly reflecting the development of a multi-hub system rather than the actual volume of origin/destination traffic between both cities per se. As a consequence, hub flows need to be considered when examining connectivity in a MAC. Demand models for hub-andspoke networks have been developed (e.g. Hendricks et al., 1995; for a useful overview, see Bryan and O'Kelly, 1999), but thus far the possible implications for MACs have not been explicitly broached. Once again, the major impediment to the development of such models may well be the lack of suitable data. The OAG data employed by Pels et al. $(2000,2001)$, for instance, do not allow singling out an airport's hub connectivity: OAG-data consist of information on route capacities rather than actually flown connections, which makes it impossible to distinguish between origin passengers and passengers making an onward connection.

Taken together, the previous discussion suggests that although deregulated air transport markets do indeed imply that MAC airports survive by attracting and accommodating enough passengers, we should bear in mind that 'airport connectivity' implies quite intricate interpretations of the general notion 'level of demand'. It is, for instance, possible that it refers to the potential volume of hub passengers (e.g. Paris Charles de Gaulle as international hub for Air France), specific types of origin/destination passengers (e.g. London City Airport as destination for short-haul business flights and London Stansted as EasyJet's base for no-frills flights to tourist destinations), or origin passengers that have been attracted through cooperation with other transport modes (e.g. intercontinental Air France passengers boarding a fast train in Brussels that brings them directly to Charles de Gaulle).

The main purpose of this paper, therefore, is to complement previous modelling exercises with a simple, but detailed empirical comparison of the chief characteristics of airport connectivities in a number of major MACs. This paper does, therefore, not report on demand 
modelling per se; the focus is on providing an introductory description of some of the scalar and functional differences between traffic at different airports in some major MACs. A large part of this detailed comparison is made possible by drawing upon a data source introduced in Derudder and Witlox (2005). This so called 'Marketing Information Data Transfer' (MIDT) data source contains information on the spatiality of actually flown, transnational connections in the period January-August 2001, which allows for a thorough assessment of the principal characteristics of specific airports. The MIDT database is now relatively old, i.e. eight years is a lifetime in the airline business. Although this has some implications for our results, the major point here is that - in contrast to standard airline statistics - MIDT data are capable of examining the 'level of demand' in much more detail than previously attempted, and so improving our understanding of the operation of MACs. Data from this source will be complemented with information from various other sources to sketch a detailed picture of the level of connectivity in some key MACs.

The remainder of this paper is organized as follows. The next section discusses the data and our framework of analysis. The third section presents the actual description of airport connectivities in some notable MACs. The fourth section discusses the main implications of our findings, and outlines some avenues for future research.

\section{FRAMEWORK OF ANALYSIS AND DATA}

In this paper, we describe the scalar and functional differentiation among airports in four major MACs, i.e. those centred on London, New York, Los Angeles, and San Francisco. O'Connor (2003, p. 91) identifies a total of 17 MACs, whereby London, New York and Los Angeles dominate this list with at least five airports. We also include San Francisco because this is arguably the most intensively researched city in this context (e.g. Harvey, 1987; Pels et al., 2000, 2001). ${ }^{4}$ For each MAC, we gauge airport connectivities and their associated spatiality. This is done separately for origin/destination (O/D) and hub flows. In addition, we examine which carriers contribute to the overall connectivity for both types of flows. Table 1 gives an overview of the airports included in the analysis.

\footnotetext{
${ }^{4}$ O'Connor's (2003) overview is based on the Airports Council International's (ACI) list of the world's busiest 100 airports and Beaverstock et al.'s (1999) world city ranking. It uses large-scale definitions of metropolitan areas. Newburgh's Stewart Airport, for instance, is considered to be a part of New York's airport system, in spite of its location more than $100 \mathrm{~km}$ away from Manhattan. The other 13 MAC's are: Chicago, Dallas, Houston, Jakarta, Las Vegas, Milan, Montreal, Moscow, Osaka, Paris, Rome, Tokyo, and Washington.
} 
Table 1: airports included in the analysis

\begin{tabular}{ll}
\hline Multiple Airport City & Airport (latacode) \\
\hline London & London City Airport (LCY) \\
& London Gatwick Airport (LGW) \\
& London Heathrow Airport (LHR) \\
& London Luton Airport (LTN) \\
& London Stansted Airport (STN) \\
& John F. Kennedy International Airport (JFK) \\
& LaGuardia Airport (LGA) \\
New York & Newark Liberty International Airport (EWR) \\
& Stewart International Airport (SWF) \\
& Westchester County Airport (HPN) \\
& Bob Hope Airport (BUR) \\
& John Wayne Airport (Orange County Airport) (SNA) \\
& Long Beach Airport (LGB) \\
& Los Angeles International Airport (LAX) \\
Ontario International Airport (ONT) & Santa Barbara Municipal Airport (SBA) \\
Charles M. Schulz Sonoma County Airport (STS) & Norman Y. Mineta San José International Airport (SJC) \\
Oakland International Airport (OAK) \\
San Francisco International Airport (SFO) \\
\end{tabular}

Arguably the most important novelty here lies in the detailed assessment of the significance and the spatiality of demand associated with an airport's hub function. One of the referees of this paper usefully pointed out that the term 'hub' has two interpretations. First, it is an airline management strategy that - when applied - creates impacts on places like Atlanta and Cleveland. Second, it is a descriptive term that reflects the level of activity on a particular indicator, thus differentiating the role of airports in a MAC network. In this paper, the term 'hub' is used in the latter sense. When used in this way, Schaafsma, (2003, p. 28) (see also Derudder et al., 2007) noted that the major airports of Atlanta, Chicago and Dallas/Fort Worth are far more important hub airports than JFK and Los Angeles International which will be analysed as MACs, both in size and dominance of the home carriers: "New York and Los Angeles are typical O/D airports: big, with considerable international travel, but with very limited roles as hubs."

The mounting importance of hub connectivity can be traced back to the fact that this organizational form allows "airlines to exploit important productive efficiencies due to the presence of economies of traffic density and economies of scope" (Nero, 1999, p. 226; see also Oum et al., 1995; Hendricks et al., 1995; Derudder et al., 2007; Derudder and Witlox, 
2009). This outcome is also associated with processes that have in turn been catalyzed by 'external trends' such as the deregulation pacts in Europe and the United States (Burghouwt and Veldhuis, 2005). It can be expected that the further liberalisation of air traffic will once again reinforce the trend towards hub-and-spoke based organization by airlines, but there are at the same time some powerful countertendencies at work. The most important countertendency is the mounting success of low-cost carriers, which are notorious for their use of a point-to-point organization. The ensuing reinstatement of large scale point-to-point models challenges the gradual shift towards hub-and-spoke networks, and this is likely to gain further pace as low-cost carriers continue to increase their market shares. It is difficult at this stage to predict how the total share of both organizational networks will evolve, but it is obvious that both systems will continue to co-exist. We gauge hub connectivity in two different ways. The first measure is the absolute hub intensity of airports ( $\mathrm{AH})$, whereby hubs are identified in terms of the total number of passengers making an onward connection. The second measure is the relative hub intensity of airports $(\mathrm{RH})$, which is computed by dividing $\mathrm{AH}$ by the total volume of passengers making use of the airport. If $\mathrm{RH}$ $=0$, then the airport functions as pure origin/destination node. If $\mathrm{RH}=1$, then the airport functions exclusively as a hub.

In the previous section, we argued that a major impediment to detailed assessments of the hub functionality of (MAC) airports is the lack of suitable data. The whole idea of a hub is that passengers make onward connections, but such information is not registered in standard airline statistics (Derudder and Witlox, 2008; Devriendt et al., 2009): standard data sources customarily gauge the individual legs of $O / D$ connections rather than the directly identifying the connections. This holds true for the OAG data employed by Pels et al. (2000, 2001), but also for the information provided by the International Civil Aviation Organization (ICAO), the International Air Transport Association (IATA), and the Association of European Airlines (AEA). In this paper, we therefore draw on a new and largely untapped data source. This so-called 'Marketing Information Data Transfer' (MIDT) database contains information on airline bookings made through so-called Global Distribution Systems (GDS). GDS are electronic platforms used by travel agencies for managing airline bookings, hotel reservations and car rentals. Well-known examples of GDS are Galileo, Apollo, Sabre, Worldspan, Amadeus, Topas, Infini and Abaccus (Shepherd Business Intelligence, 2004) Miller (1999) estimates that as late as 1999 , more than $80 \%$ of airline bookings were made through GDS. The connections that are not being recorded in the MIDT database primarily pertain to low-cost carriers such as EasyJet. The connectivity of London's 'low cost'-oriented airports (Stansted and Luton), for instance, will therefore likely be underestimated in the analysis that follows. It also implies that it is not straightforward to gauge the relative importance of individual carriers at such airports. Another similar and very useful dataset available for the US aviation market is the USDOT 10\% ticket sample. This dataset includes the full flight itinerary from origin, through hub(s) connections, to destination airport for $10 \%$ of all US flights. Our MIDT dataset, however, contains global flight information, which 
makes it more useful for our purposes. For every GDS-based booking, the MIDT database records information on airline codes, flight numbers, O/D airports, switching points (if any), booking date, departure date, agency name, cancellation indicators, and so on. Through the cooperation of an airline, we were able to make use $f$ a MIDT database covering the period January-August 2001. The dataset contains information on a total of $547,410,397$ passengers movements, $127,288,181$ of which pertain in one way or the other to the four MACs under investigation. Table 2 gives the reader an idea of the basic outline of the MIDT database. Because of the specific way in which the data were recorded, it becomes possible to distinguish between an airport's O/D flows ("ORIGIN" and "DESTINATION" fields) and its hub connectivity ("CXN1" and "CXN2" fields).

Table 2: excerpt of the MIDT database

\begin{tabular}{lllllllll}
\hline origin & destination & numseg & carrier1 & carrier2 & carrier3 & cnx1 & cnx2 & total pax \\
\hline LHR & BLQ & 1 & BA & & & & & 37746 \\
LHR & LAS & 1 & UA & & & & & 2446 \\
LHR & ATH & 2 & LH & LH & & FRA & & 1944 \\
LHR & OAK & 2 & UA & UA & & ORD & & 57 \\
LHR & GCM & 3 & AA & AA & AA & JFK & MIA & 130 \\
LHR & ISB & 3 & GF & GF & GF & BAH & AUH & 269 \\
\hline
\end{tabular}

\section{AIRPORT CONNECTIVITIES IN MAJOR MACS}

\subsection{Origin/destination flows}

Table 3 presents an overview of airport O/D connectivity in each of the four MACs. The table lists the total volume of passengers for each airport, and unravels the spatiality behind this overall connectivity; spatial patterns are assessed (i) by distinguishing between national and international flows and (ii) through a more wide-ranging regional breakdown of passenger movements.

Table 3: airport O/D connectivity in each of the four MACs (situation 2001) 


\begin{tabular}{|c|c|c|c|c|c|c|c|c|c|c|c|c|}
\hline \multirow[b]{2}{*}{ Airport } & \multirow[b]{2}{*}{ OD pax } & \multirow[b]{2}{*}{$\%$ national } & \multicolumn{10}{|l|}{$\%$} \\
\hline & & & international & $\%$ region & & & & & & & & \\
\hline LONDON & & & & Europe & N-Am & Latin Am & \begin{tabular}{|l|} 
E-Asia \& \\
Pac
\end{tabular} & MENA & $\begin{array}{l}\text { FSU/C- } \\
\text { Asia }\end{array}$ & Oceania & S-Asia & $\begin{array}{l}\text { Sub-Sah } \\
\text { Afr }\end{array}$ \\
\hline London Heathrow Airport & 26680723 & $8 \%$ & $92 \%$ & $53,63 \%$ & $19,24 \%$ & $2,15 \%$ & $7,70 \%$ & $6,14 \%$ & $0,80 \%$ & $2,79 \%$ & $3,65 \%$ & $3,91 \%$ \\
\hline London Gatwick Airport & 7846817 & $12 \%$ & $88 \%$ & $53,20 \%$ & $31,50 \%$ & $7,28 \%$ & $0,79 \%$ & $1,24 \%$ & $1,05 \%$ & $0,07 \%$ & $0,38 \%$ & $4,48 \%$ \\
\hline London Stansted Airport & 1388933 & $10 \%$ & $90 \%$ & $93,15 \%$ & $2,73 \%$ & $0,51 \%$ & $0,71 \%$ & $1,91 \%$ & $0,17 \%$ & $0,09 \%$ & $0,18 \%$ & $0,56 \%$ \\
\hline London City Airport & 902607 & $23 \%$ & $77 \%$ & $98,41 \%$ & $0,36 \%$ & $0,20 \%$ & $0,23 \%$ & $0,19 \%$ & $0,06 \%$ & $0,01 \%$ & $0,06 \%$ & $0,47 \%$ \\
\hline London Luton Airport & 198295 & $17 \%$ & $83 \%$ & $99,98 \%$ & $0,00 \%$ & $0,00 \%$ & $0,00 \%$ & $0,01 \%$ & $0,00 \%$ & $0,00 \%$ & $0,00 \%$ & $0,00 \%$ \\
\hline NEW YORK & & & & Europe & N-Am & Latin Am & \begin{tabular}{|l|} 
E-Asia \& \\
Pac
\end{tabular} & MENA & $\begin{array}{l}\text { FSU/C- } \\
\text { Asia }\end{array}$ & Oceania & S-Asia & $\begin{array}{l}\text { Sub-Sah } \\
\text { Afr }\end{array}$ \\
\hline John F. Kennedy International Airport & 15650776 & $24 \%$ & $76 \%$ & $30,89 \%$ & $25,33 \%$ & $25,65 \%$ & $7,21 \%$ & $4,39 \%$ & $1,14 \%$ & $0,48 \%$ & $3,28 \%$ & $1,64 \%$ \\
\hline Newark Liberty International Airport & 13758248 & $63 \%$ & $37 \%$ & $15,70 \%$ & $66,51 \%$ & $12,71 \%$ & $2,41 \%$ & $1,55 \%$ & $0,13 \%$ & $0,11 \%$ & $0,62 \%$ & $0,25 \%$ \\
\hline LaGuardia Airport & 10214707 & $87 \%$ & $13 \%$ & $0,40 \%$ & $93,38 \%$ & $5,44 \%$ & $0,70 \%$ & $0,06 \%$ & $0,00 \%$ & $0,01 \%$ & $0,00 \%$ & $0,01 \%$ \\
\hline Westchester County Airport & 384089 & $97 \%$ & $3 \%$ & $0,18 \%$ & $99,31 \%$ & $0,23 \%$ & $0,26 \%$ & $0,00 \%$ & $0,00 \%$ & $0,01 \%$ & $0,00 \%$ & $0,00 \%$ \\
\hline Stewart International Airport & 177386 & $98 \%$ & $2 \%$ & $0,52 \%$ & $98,34 \%$ & $0,84 \%$ & $0,26 \%$ & $0,01 \%$ & $0,00 \%$ & $0,03 \%$ & $0,00 \%$ & $0,00 \%$ \\
\hline LOS ANGELES & & & & Europe & N-Am & Latin Am & \begin{tabular}{|l|} 
E-Asia \& \\
Pac
\end{tabular} & MENA & $\begin{array}{l}\text { FSU/C- } \\
\text { Asia }\end{array}$ & Oceania & S-Asia & $\begin{array}{l}\text { Sub-Sah } \\
\text { Afr }\end{array}$ \\
\hline Los Angeles International Airport & 22275989 & $55 \%$ & $45 \%$ & $8,91 \%$ & $59,09 \%$ & $14,24 \%$ & $12,98 \%$ & $0,94 \%$ & $0,16 \%$ & $3,02 \%$ & $0,49 \%$ & $0,17 \%$ \\
\hline $\begin{array}{l}\text { John Wayne Airport } \\
\text { (Orange County Airport) }\end{array}$ & 2399095 & $97 \%$ & $3 \%$ & $0,68 \%$ & $98,29 \%$ & $0,74 \%$ & $0,25 \%$ & $0,02 \%$ & $0,00 \%$ & $0,00 \%$ & $0,00 \%$ & $0,01 \%$ \\
\hline Ontario International Airport & 1526880 & $95 \%$ & $5 \%$ & $0,50 \%$ & $96,96 \%$ & $2,27 \%$ & $0,20 \%$ & $0,02 \%$ & $0,01 \%$ & $0,02 \%$ & $0,01 \%$ & $0,01 \%$ \\
\hline Bob Hope Airport & 793641 & $99 \%$ & $1 \%$ & $0,10 \%$ & $99,65 \%$ & $0,13 \%$ & $0,12 \%$ & $0,00 \%$ & $0,00 \%$ & $0,00 \%$ & $0,00 \%$ & $0,00 \%$ \\
\hline Santa Barbara Municipal Airport & 222403 & $89 \%$ & $11 \%$ & $3,78 \%$ & $92,13 \%$ & $1,80 \%$ & $1,70 \%$ & $0,11 \%$ & $0,02 \%$ & $0,38 \%$ & $0,04 \%$ & $0,04 \%$ \\
\hline Long Beach Airport & 218467 & $99 \%$ & $1 \%$ & $0,12 \%$ & $99,54 \%$ & $0,32 \%$ & $0,00 \%$ & $0,00 \%$ & $0,00 \%$ & $0,00 \%$ & $0,00 \%$ & $0,00 \%$ \\
\hline SAN FRANCISCO & & & & Europe & N-Am & Latin Am & \begin{tabular}{|l|} 
E-Asia \& \\
Pac
\end{tabular} & MENA & \begin{tabular}{|l|} 
FSU/C- \\
Asia
\end{tabular} & Oceania & S-Asia & $\begin{array}{l}\text { Sub-Sah } \\
\text { Afr }\end{array}$ \\
\hline San Francisco International Airport & 12297086 & $56 \%$ & $44 \%$ & $13,67 \%$ & $60,30 \%$ & $6,24 \%$ & $16,16 \%$ & $0,78 \%$ & $0,20 \%$ & $1,07 \%$ & $1,38 \%$ & $0,19 \%$ \\
\hline $\begin{array}{l}\text { Norman Y. Mineta San José } \\
\text { International Airport }\end{array}$ & 3442422 & $88 \%$ & $12 \%$ & $1,42 \%$ & $90,86 \%$ & $4,80 \%$ & $2,58 \%$ & $0,08 \%$ & $0,01 \%$ & $0,16 \%$ & $0,07 \%$ & $0,02 \%$ \\
\hline Oakland International Airport & 2019534 & $94 \%$ & $6 \%$ & $0,26 \%$ & $95,19 \%$ & $4,29 \%$ & $0,09 \%$ & $0,01 \%$ & $0,00 \%$ & $0,14 \%$ & $0,01 \%$ & $0,01 \%$ \\
\hline Charles M. Schulz Sonoma County Airport & 15363 & $95 \%$ & $5 \%$ & $0,89 \%$ & $95,54 \%$ & $1,89 \%$ & $0,50 \%$ & $0,05 \%$ & $0,01 \%$ & $1,03 \%$ & $0,08 \%$ & $0,02 \%$ \\
\hline
\end{tabular}

In terms of load division among the different airports, New York and Los Angeles have very different profiles. In New York, there are three airports with - roughly speaking - similar levels of O/D connectivity (John F. Kennedy, LaGuardia, and Newark). In Los Angeles, in contrast, one airport towers above all the others (Los Angeles International with about 10 times more passengers than John Wayne in Orange County). London and San Francisco have an in-between profile: in each case one airport dominates the MAC system, but this dominance is far less profound than in Los Angeles. As shown in the data Heathrow and San Francisco International boast 3-4 times more O/D passengers than the second most important airport in their respective MACs (Gatwick and San José International respectively).

In addition to the presence of one or more dominant airport(s), each MAC has one or more airports serving a relatively small volume of passengers. Table 3 suggests that these smaller airports have, in general, a regional connectivity profile: airports such as Stewart in New York, Long Beach in Los Angeles, and Sonoma County in San Francisco have limited 
connectivities that are almost exclusively oriented to other US cities. It is perhaps useful to remember that this spatiality is not an artefact of the data, since our data cover genuine $O / D$ flows rather than offered capacities from/to specific airports. Nor should these lower connectivities be seen as reflecting a 'less competitive' position in terms of the level of demand. Rather, they should be attributed to a number of different factors that (sometimes temporarily) constrain the development of the airport. One of the big impediments for the development of Stewart Airport, for instance, was not necessarily that there was no airport capacity, but rather that getting to the airport was difficult. The completion of Interstate 1984's new Drury Lane exit, in 2007 and the accompanying access road to the airport were explicitly intended to remedy this problem (Randall 2007). The relatively small size of Long Beach Airport, in turn, is due to ordinances adopted to minimize noise in the residential neighbourhoods. The current noise levels allow for a maximum of 41 daily commercial flights and 25 commuter flights (http://www.longbeach.gov/airport/green/default.asp, last accessed 8/7/2009) so that the reduced connectivity is less driven by the level of demand than by the setting of the airport. In the case of Sonoma County Airport, the only commercial airline service in 2001 was operated by United Express which subsequently was halted because the flights (to San Francisco and Los Angeles) were not profitable. In the period 2001-2007, the airport was exclusively used for general aviation. Recently, commercial aviation services have returned: additional routes brought new hope that other airlines will start flying into Sonoma County. In general, airports with sizable O/D connectivities have a more developed international profile. In each of the three US MACS, the most important airport is also by far the most international airport. This is of course related to the number/length of runways at the major airports: the aircraft types most commonly used for intercontinental travel (B747, B767, B777, A340, A380, etc.) need runways of at least $7000-8000 \mathrm{ft}$ to take off. Thus, JFK with its four runways with lengths between $8400 \mathrm{ft}$ and 14,500 ft is well-suited for these aircraft, while Westchester County Airport, with two runways of $4451 \mathrm{ft}$ and $6548 \mathrm{ft}$, respectively, is ill-equipped. In San Francisco and Los Angeles, only the leading airports - with four runways of $8000-12,000 \mathrm{ft}$ exhibits a substantial international O/D profile. The international connections of San Francisco International and Los Angeles International are predominantly oriented on Latin America, Europe and Pacific Asia, albeit that San Francisco International has relatively stronger connections to European and Pacific Asian cities. In New York, things are a little bit more complex. Despite similar levels of O/D connectivity, there is a clear-cut difference between John F. Kennedy (JFK) as a truly international airport (only $25 \%$ of O/D passengers travel to/from a US city) and LaGuardia as national airport (more than $90 \%$ of O/D passengers travel to/from a US city). Once again, this is related to the capacities of both airports: JFK's four long runways outweigh LaGuardia's two 7000ft runways, which makes the latter de facto less attractive for intercontinental flights. JFK thus clearly functions as New York's prime gateway for air transportation to/from other parts of the world, with important connections to European (31\%) and Latin American (26\%) cities. Newark takes on an in-between position in New York's MAC system: a sizable dominance of US flows (63\%) is 
coupled with relatively important O/D flows to European (16\%) and Latin American (13\%) cities. Given the small size of the UK, and hence its much smaller domestic air network, a division between international and national connections is less effective when comparing the O/D connectivities in London's MAC system. Relating the outcome in the UK to the US situation it is necessary to utilize a separate category for European flights, reserving the term international for all long distance connections. As in US MACs, the leading airport (Heathrow) is also the most international airport; its connections can be seen in important flows to cities in South and Pacific Asia, the Middle East, and Oceania, in addition to the US. Gatwick is at least as 'international' as Heathrow, with almost $50 \%$ of its O/D passengers flying to/from non-European cities. However, there is a clear-cut spatial division between these two airports: Gatwick's international passengers are predominantly flying to US and to a lesser degree - Latin American cities. Recently, however, Gatwick's traffic pattern have been changing rapidly because of (partial) pull-outs by British Airways and other major carriers such as Continental Airlines and American Airlines. The slots vacated by these moves were taken by EasyJet, Flybe and Ryanair, which will likely transform the airport from a secondary intercontinental hub into a predominantly European and domestic operation feeding London and specifically the market south of London.

But as the regional markets section of the table shows the real differences are to be found in the volume of flows to/from other European cities. Stansted, City and Luton are very closely tied to the European market. For each airport, Table 4 lists carriers according to their contribution to the total O/D connectivity. All US MAC airports are dominated by US-based carriers. The table reveals some basic patterns of corporate organization, such as the control over Newark and JFK by Continental Airlines and American Airlines respectively. In general, however, there are few signs of monopoly formation (at least at the level of the airports, this is not necessarily the case for specific flows to/from the airport): although one carrier may surpass others in terms of O/D-flows, there are almost always other carriers with a significant market share. In the deregulated US air transport market, even small airports such as Westchester and Stewart are served by multiple carriers. ${ }^{5}$

Table 4: OD carriers (situation 2001)

\footnotetext{
${ }^{5}$ Perhaps the only exception is Charles M. Schulz Sonoma County Airport, which in this data was dominated by United Airlines.
} 


\begin{tabular}{|c|c|c|c|c|c|}
\hline Airport & OD Carrier & OD pax & Airport & OD Carrier & OD pax \\
\hline LONDON & & & LOS ANGELES & & \\
\hline \multirow[t]{3}{*}{ London Heathrow Airport } & British Airways (United Kingdom) & 9167342 & Los Angeles International Airport & United Airlines (United States) & 4527924 \\
\hline & BMI (United Kingdom) & 2142753 & & American Airlines (United States) & 3634479 \\
\hline & Lufthansa (Germany) & 1511144 & & Delta Airlines (United States) & 2214986 \\
\hline \multirow[t]{3}{*}{ London Gatwick Airport } & British Airways (United Kingdom) & 4350857 & John Wayne Airport (Orange County Airport) & American Airlines (United States) & 871158 \\
\hline & Virgin Atlantic Airways (United Kingdom) & 633108 & & United Airlines (United States) & 525601 \\
\hline & Continental Airlines (United States) & 618719 & & American West Airlines (United States) & 458326 \\
\hline \multirow[t]{3}{*}{ London Stansted Airport } & Lufthansa (Germany) & 388163 & Ontario International Airport & Southwest Airlines (United States) & 447372 \\
\hline & Ryanair (Ireland) & 364659 & & United Airlines (United States) & 431655 \\
\hline & KLM Royal Duth Airlines (Netherlands) & 224163 & & Delta Airlines (United States) & 320235 \\
\hline \multirow[t]{3}{*}{ London City Airport } & Swiss International Air Lines (Switzerland) & 149087 & Bob Hope Airport & Southwest Airlines (United States) & 387857 \\
\hline & British European (United Kingdom) & 123227 & & United Airlines (United States) & 246981 \\
\hline & Air France (France) & 98674 & & American West Airlines (United States) & 154198 \\
\hline \multirow[t]{4}{*}{ London Luton Airport } & Monarch Airlines (United Kingdom) & 128603 & Santa Barbara Municipal Airport & United Airlines (United States) & 215814 \\
\hline & Ryanair (Ireland) & 21076 & & American Airlines (United States) & 86903 \\
\hline & British European (United Kingdom) & 15953 & & American West Airlines (United States) & 55548 \\
\hline & & & Long Beach Airport & American Airlines (United States) & 169385 \\
\hline NEW YORK & & & & American West Airlines (United States) & 125053 \\
\hline \multirow[t]{3}{*}{ John F. Kennedy International Airport } & American Airlines (United States) & 3470136 & & Continental Airlines (United States) & 2770 \\
\hline & Delta Airlines (United States) & 1653467 & & & \\
\hline & Trans World Airlines (United States) & 1651872 & SAN FRANCISCO & & \\
\hline \multirow[t]{3}{*}{ Newark Liberty International Airport } & Continental Airlines (United States) & 7307812 & San Francisco International Airport & United Airlines (United States) & 4584988 \\
\hline & American Airlines (United States) & 1467271 & & American Airlines (United States) & 1603583 \\
\hline & Delta Airlines (United States) & 1233871 & & Delta Airlines (United States) & 1028300 \\
\hline \multirow[t]{3}{*}{ LaGuardia Airport } & US Airways (United States) & 2717430 & Norman Y. Mineta San José International Airport & American Airlines (United States) & 1633567 \\
\hline & Delta Airlines (United States) & 2640095 & & United Airlines (United States) & 659726 \\
\hline & American Airlines (United States) & 2321479 & & Southwest Airlines (United States) & 443195 \\
\hline \multirow[t]{3}{*}{ Westchester County Airport } & American Airlines (United States) & 128517 & Oakland International Airport & Southwest Airlines (United States) & 715982 \\
\hline & US Airways (United States) & 113640 & & United Airlines (United States) & 560225 \\
\hline & United Airlines (United States) & 92456 & & American Airlines (United States) & 359137 \\
\hline \multirow[t]{3}{*}{ Stewart International Airport } & American Airlines (United States) & 81953 & Charles M. Schulz Sonoma County Airport & United Airlines (United States) & 23745 \\
\hline & Midway Airlines (United States) & 77878 & & American Airlines (United States) & 240 \\
\hline & Delta Airlines (United States) & 61580 & & Del ta Airlines (United States) & 204 \\
\hline
\end{tabular}

London's most important airports (Heathrow and Gatwick) are dominated by British Airways. The significance of US flows from/to Gatwick is exemplified by the important position of Virgin Atlantic Airways (which specializes in US flights) and US carrier Continental Airlines. Flights offered by non-UK carriers encompass a significant share of London's airline market: Lufthansa is ranked 3rd at Heathrow, while back in 2001 SwissAir held a more important position at the business airport, London City, than any other (UK) carrier.

\subsection{Hub flows}

Table 5 presents an overview of airport hub connectivity in each of the four MACs. The AH and $\mathrm{RH}$ rankings are complemented with a simple measure of 'internationality'. This is achieved by distinguishing between international, regional, and mixed international/ regional hub flows: (i) an "international" hub function involves connections to cities in other regions: e.g. John F. Kennedy for the connection Brussels-Mexico City; (ii) a 'regional' hub function involves connections to cities in the home region: e.g. LaGuardia for the connection Chicago-Orlando; and (iii) a 'mixed international/regional' hub function involves connections 
between city in the home region and a city in another region: e.g. Newark for the connection Amsterdam-Denver. ${ }^{6}$

The first and most obvious pattern is that, taken together, in MACs the most important O/D airports are also the major hub airports. Los Angeles' one-airport dominance in terms of O/D flows, for instance, re-emerges: Los Angeles International is the only airport with significant hub flows. The only exceptions are LaGuardia and Oakland Metropolitan, which have far fewer hub passengers than JFK/Newark and San Francisco International/San José International respectively. This implies that La Guardia exhibits totally different scalar and functional characteristics than JFK and Newark: it is an O/D airport with an unambiguous national focus. A similar observation can be made for Oakland Metropolitan. In New York's MAC system, Newark's hub function is a little bit more important than JFK in both absolute and relative terms (see also Schaafsma, 2003, p. 30). However, JFK has a more developed international profile; only $4 \%$ of JFK's hub passengers travel between North American cities (30\% for Newark). Although San José International connects a sizable number of hub passengers, it is far less important in absolute and in relative terms than San Francisco International. The latter also enjoys a more international profile: $56 \%$ of its hub passengers fly to/from a city outside North America. In London's MAC system, Heathrow dominates all other airports in absolute volume of hub passengers. However, in relative terms, Gatwick stays in tune with about $14 \%$ of all passengers making an onward connection. The spatiality of their hub functions is more or less comparable, with Heathrow connecting more international passengers.

For each airport, Table 6 lists carriers according to their contribution to the airport's total hub connectivity. The table also features the total number of carriers connecting passengers at that airport (with a threshold of 1000 hub passengers during the period under investigation). In general, the rankings largely replicate those for O/D flows. There is, however, one major difference: the 'gaps' between different carriers are considerably bigger. Thus, while Continental serves five times more O/D passengers at Newark than runner-up American Airlines, it serves about 100 times more hub passengers. A major exception is JFK, where Delta is ranked first in terms of hub flows, whereas it is only the second most important carrier for genuine O/D flows.

Table 5: airport hub connectivity in each of the four MACs (situation 2001)

\footnotetext{
${ }^{6}$ The use of the term 'connected airports' hereby refers to a passenger's actual place of origin/destination. This means that when a passengers makes two or more intermediate stopovers, the hub function of the switching points is considered visàvis the O/D-airports rather than the backward and forward linkages. The use of the term 'regional', in turn, refers to the regions considered in Table 3.
} 


\begin{tabular}{|c|c|c|c|c|c|}
\hline \multirow[b]{2}{*}{ Airport } & \multirow[b]{2}{*}{$\mathrm{AH}$} & \multirow[b]{2}{*}{ RH } & \multicolumn{3}{|c|}{$\%$ mixed } \\
\hline & & & \% regional & international/regional & $\%$ international \\
\hline \multicolumn{6}{|l|}{ LONDON } \\
\hline London Heathrow Airport & 4523686 & $15 \%$ & $15 \%$ & $65 \%$ & $20 \%$ \\
\hline London Gatwick Airport & 1302004 & $14 \%$ & $22 \%$ & $64 \%$ & $14 \%$ \\
\hline London City Airport & 15245 & $2 \%$ & $98 \%$ & $2 \%$ & $0 \%$ \\
\hline London Stansted Airport & 7447 & $1 \%$ & $83 \%$ & $14 \%$ & $3 \%$ \\
\hline London Luton Airport & 75 & $0 \%$ & $60 \%$ & $40 \%$ & $0 \%$ \\
\hline \multicolumn{6}{|l|}{ NEW YORK } \\
\hline Newark Liberty International Airport & 2007555 & $13 \%$ & $30 \%$ & $65 \%$ & $6 \%$ \\
\hline John F. Kennedy International Airport & 1565894 & $9 \%$ & $4 \%$ & $90 \%$ & $6 \%$ \\
\hline LaGuardia Airport & 202471 & $2 \%$ & $81 \%$ & $19 \%$ & $0 \%$ \\
\hline Westchester County Airport & 568 & $0 \%$ & $100 \%$ & $0 \%$ & $0 \%$ \\
\hline Stewart International Airport & 7 & $0 \%$ & $100 \%$ & $0 \%$ & $0 \%$ \\
\hline \multicolumn{6}{|l|}{ LOS ANGELES } \\
\hline Los Angeles International Airport & 3654304 & $14 \%$ & $42 \%$ & $54 \%$ & $4 \%$ \\
\hline John Wayne Airport (Orange County Airport) & 11199 & $0 \%$ & $100 \%$ & $0 \%$ & $0 \%$ \\
\hline Ontario International Airport & 1419 & $0 \%$ & $98 \%$ & $2 \%$ & $0 \%$ \\
\hline Bob Hope Airport & 377 & $0 \%$ & $100 \%$ & $0 \%$ & $0 \%$ \\
\hline Santa Barbara Municipal Airport & 270 & $0 \%$ & $100 \%$ & $0 \%$ & $0 \%$ \\
\hline Long Beach Airport & 2 & $0 \%$ & $100 \%$ & $0 \%$ & $0 \%$ \\
\hline \multicolumn{6}{|l|}{ SAN FRANCISCO } \\
\hline San Francisco International Airport & 1743181 & $12 \%$ & $44 \%$ & $55 \%$ & $1 \%$ \\
\hline Norman Y. Mineta San José International Airport & 200608 & $6 \%$ & $62 \%$ & $38 \%$ & $0 \%$ \\
\hline Oakland International Airport & 20802 & $1 \%$ & $99 \%$ & $1 \%$ & $0 \%$ \\
\hline Charles M. Schulz Sonoma County Airport & 0 & $0 \%$ & $0 \%$ & $0 \%$ & $0 \%$ \\
\hline
\end{tabular}

British Airways dominates hub connectivity at both Heathrow and Gatwick. It is clear that until recently British Airways pursued a double-hub strategy, in which both were are considered to be viable switching points in London's MAC system. This strategic approach has been materialized through schemes such as the mid-1990s Jupiter project (Starkie, 2002). This project involved moving some long haul routes (especially African connections) from Heathrow to Gatwick. The freed slots at Heathrow were thereupon used for other services. Since then, there has been a continuous re-shuffling of British Airways routes between these airports. 
Table 6: Hub carriers (situation 2001)

\begin{tabular}{|c|c|c|c|}
\hline \multirow{2}{*}{$\begin{array}{l}\text { Airport } \\
\text { LONDON }\end{array}$} & \multirow[t]{2}{*}{ Hub Carrier } & \multicolumn{2}{|c|}{ AH \# hub carriers } \\
\hline & & & \\
\hline \multirow[t]{3}{*}{ London Heathrow Airport } & British Airways (United Kingdom) & 5182044 & 78 \\
\hline & BMI (United Kingdom) & 673445 & \\
\hline & United Airlines (United States) & 421223 & \\
\hline \multirow[t]{3}{*}{ London Gatwick Airport } & British Airways (United Kingdom) & 2170934 & 30 \\
\hline & Virgin Atlantic Airways (United Kingdom) & 80301 & \\
\hline & Emirates Airlines (United Arab Emirates) & 57167 & \\
\hline \multirow[t]{3}{*}{ London City Airport } & Swiss International Air Lines (Switzerland) & 8913 & 6 \\
\hline & British European (United Kingdom) & 6223 & \\
\hline & Air Lingus (Republic of Ireland) & 5430 & \\
\hline \multirow[t]{2}{*}{ London Stansted Airport } & Ryanair (Ireland) & 7041 & 2 \\
\hline & Lufthansa (Germany) & 1119 & \\
\hline London Luton Airport & - & - & 0 \\
\hline \multicolumn{4}{|l|}{ NEW YORK } \\
\hline \multirow{3}{*}{ Newark Liberty International Airport } & Continental Airlines (United States) & 3540957 & 28 \\
\hline & Scandinavian Airlines (Denmark, Normway, Sweden) & 68753 & \\
\hline & Northwest Airlines (United States) & 55870 & \\
\hline \multirow[t]{3}{*}{ John F. Kennedy International Airport } & Delta Airlines (United States) & 1394978 & 60 \\
\hline & American Airlines (United States) & 796171 & \\
\hline & Trans World Airlines & 187579 & \\
\hline \multirow[t]{3}{*}{ LaGuardia Airport } & US Airways (United States) & 220518 & 15 \\
\hline & American Airlines (United States) & 100503 & \\
\hline & Delta Airlines (United States) & 27634 & \\
\hline Westchester County Airport & - & - & 0 \\
\hline Stewart International Airport & - & - & 0 \\
\hline \multicolumn{4}{|l|}{ LOS ANGELES } \\
\hline \multirow[t]{3}{*}{ Los Angeles International Airport } & United Airlines (United States) & 2618101 & 57 \\
\hline & American Airlines (United States) & 1391147 & \\
\hline & Delta Airlines (United States) & 530091 & \\
\hline \multirow[t]{3}{*}{ John Wayne Airport (Orange County Airport) } & American West Airlines (United States) & 16433 & 3 \\
\hline & American Airlines (United States) & 3144 & \\
\hline & United Airlines (United States) & 1514 & \\
\hline Ontario International Airport & Southwest Airlines (United States) & 1818 & 1 \\
\hline Bob Hope Airport & - & - & 0 \\
\hline Santa Barbara Municipal Airport & - & - & 0 \\
\hline Long Beach Airport & - & - & 0 \\
\hline \multicolumn{4}{|l|}{ SAN FRANCISCO } \\
\hline \multirow[t]{3}{*}{ San Francisco International Airport } & United Airlines (United States) & 2990815 & 32 \\
\hline & Northwest Airlines (United States) & 65166 & \\
\hline & Alaska Airlines (United States) & 54890 & \\
\hline \multirow[t]{3}{*}{ Norman Y. Mineta San José International Airport } & American Airlines (United States) & 361143 & 5 \\
\hline & Southwest Airlines (United States) & 20997 & \\
\hline & Alaska Airlines (United States) & 10966 & \\
\hline \multirow[t]{2}{*}{ Oakland International Airport } & Southwest Airlines (United States) & 36323 & 2 \\
\hline & Alaska Airlines (United States) & 3198 & \\
\hline Charles M. Schulz Sonoma County Airport & - & - & 0 \\
\hline
\end{tabular}




\section{DISCUSSION AND AVENUES FOR FURTHER RESEARCH}

In the previous section, we presented a straightforward overview of airport connectivity in some major MACs. All in all, the various tables contain few surprises. It is, for instance, well established that Continental's position in New York's MAC system reflects its Newarkconcentrated strategy involving sizable hub operation. However, the major point here is that, in contrast to standard airline statistics, MIDT data are effectively capable of revealing the levels of differences between the component airports in the MACs studied here, which opens up numerous possibilities for further research on air transport in general and MACs in particular. Such future MAC research could for example utilize a more refined regional and international spatial dis-aggregation of the data to reveal some interesting patterns.

Perhaps more importantly, the tables and associated discussion suggests that MAC research should not be narrowed down to airport competition. Rather the focus needs to be upon the complementarities between MAC airports. That focus opens up the need to look at what happens on the ground in MACs. For instance, both to understand and take advantage of connectivity in a MAC, it is necessary to consider how a transfer strategy can be integrated with ground transportation between the airports. At present, major carriers, and the regional planning and management agencies spend little time and effort on this aspect. In London, British Airways suggests a minimum connection time of $3 \mathrm{~h}$ for a Gatwick/ Heathrow change, while the airports are only 30 miles apart; In Paris, something similar applies to Air France's Orly/Charles de Gaulle-connection system. The integration could be implemented at the level of the individual airports (rather than individual carriers) or even the MAC as a whole. Thinking along those lines will involve an elaborate mass transport system that interconnects the city and its airports which may be a big plus in terms of increasing capacity in the overall system of airports. In the Bay Area, for instance, the Bay Area Rapid Transit (BART), a heavy-rail public transportation system, already connects the city with San Francisco International Airport and Oakland International Airport. Furthermore, BART also has direct connections with regional rail services providing fast services all the way to San José. Expansion projects for BART include the San José and the Oakland Airport Connector which would help fully integrate the Bay Area MAC, thus opening up new possibilities for individual airports, airlines and passengers.

Other promising research opportunities are to be found in refining and extending the approaches to the analysis of demand at MACs These refinements will not necessarily entail fully fledged hub demand models for MACs per se, but rather require a re-thinking of current approaches. First, it seems highly unlikely that existing hub models can be applied to MAC systems. After all, the specifications of MACs was independent of their relevance in the context of hub-and-spoke networks. When examining competition for origin passengers, it can readily be assumed that a MAC represents a meaningful unit of analysis, as they are 
usually very large, globally significant cities. But MAC airports face far greater competition when it comes down to hub roles. In fact, the hub role may be less relevant in MACs as, in general, they are not major transaction centres for passenger flows. As noted earlier, it is well known that well-connected MACs such as London, New York and Los Angeles are not necessarily major hubs in airline networks (Derudder et al., 2007; see also Schaafsma, 2003; De Neufville and Odoni, 2003; see, however, Pels et al., 1997). This is because the basic conditions for ideal hub functioning are not met due to the O/D-related congestion around MACs associated with their sheer attraction as destinations. For airlines it becomes increasingly fruitful to bypass them when organizing route structures. Centrally located cities in less important urban areas with relatively limited O/D traffic (e.g., St. Louis, Cincinnati and Dallas) can offer reliable schedules and cost savings associated with hub operation. That means, in spite of some spatial constraints, a passenger travelling from Brussels to San Francisco has many alternative hub options other than the MACs studied here at his/her disposal. Taken together, this implies that competition for hub passengers may well be a very difficult proposition for MACs: it involves airports beyond the MAC system, and MAC attractiveness for hub functions is increasingly being downplayed because of locational and capacity constraints.

However, this does not imply that consideration of hub flows is trivial. First, because of the sheer size of their O/D-market, major MACs will likely remain reasonably important hubs in absolute terms. And second, because an airline's choice for a specific airport is disproportionately influenced by prospective hub passengers, these connections will need to represent a crucial element in demand models. This disproportionate importance of hub passengers can be traced back to the observation that O/D carriers have far more scope for switching operations between different airports than hub carriers. The major implication here is that an airline's choice for a specific MAC airport may in large part be driven by the prospective volume of hub passengers, even if these amount only to a relative small proportion of the overall connectivity. In London, British Airways is capable of sustaining two hub airports because of its sheer market dominance (coupled with the city's prime position in global airline networks; see also Berechman and De Wit, 1996). In US MACs, however, achieving and sustaining market dominance is more difficult because of the large number of competing carriers and hubs. As a consequence, empirical insight in the volume and the spatiality of hub flows is of prime importance for modelling the complex mechanisms driving demand in MACs. In summary the internal organization of MACs, as well as their intercity competitive position, hold the bones of an interesting air transport research agenda.

\section{Acknowledgements}

We would like to thank the editor and the reviewers for their useful comments on an earlier version of this paper. The usual disclaimers apply. This research work is funded by the Research Foundation-Flanders, Grant Number G.0214.04. 


\section{REFERENCES}

Ashford, N., Benchemam, M., 1987. Passengers' choice of airport, an application of the multinomial logit model. Transportation Research Record 1147, 1-5.

Beaverstock, J.V., Smith, R.G., Taylor, P.J., 1999. A roster of world cities. Cities 16 (6), 445458.

Berechman, J., de Wit, J., 1996. An analysis of the effects aviation deregulation on an airline's choice of a primary West European airport. Journal of Transport Economics and Policy 30, 251-274.

Bryan, D.L., O'Kelly, M.E., 1999. Hub-and-spoke networks in air transportation, an analytical review. Journal of Regional Science 39 (2), 275-295.

Burghouwt, G., Veldhuis, J., 2005. De concurrentiepositie van hub-luchthavens op de transatlantisch markt [The competitiveness of hub airports on the transatlantic airline market]. Tijdschrift Vervoerswetenschappen 41 (2), 2-10.

Button, K., 2002. Debunking some myths about airport hubs. Journal of Air Transport Management 8 (3), 177-188.

De Neufville, R., 1976. Guessing at the Future. Airport Systems Planning. Macmillan, London, England. MIT Press, Cambridge, MA (Chapter 3).

De Neufville, R., 1984. Planning for multiple airports in a metropolitan region. Built Environment (special issue) 10 (3), 159-167.

De Neufville, R., Odoni, A., 2003. Airport Systems Planning, Design, and Management. McGraw-Hill, New York, NY.

Derudder, B., Witlox, F., 2005. An appraisal of the use of airline data in assessing the world city network. A research note on data. Urban Studies 42, 2371-2388.

Derudder, B., Witlox, F., 2008. Mapping global city networks through airline flows: context, relevance, and problems. Journal of Transport Geography 16, 305-312.

Derudder, B., Witlox, F., 2009. The impact of progressive liberalization on the spatiality of airline networks: a measurement framework based on the assessment of hierarchical differentiation. Journal of Transport Geography 17, 276-284.

Derudder, B., Devriendt, L., Witlox, F., 2007. Flying where you don't want to go. An empirical analysis of hubs in the global airline network. Tijdschrift voor Economische en Sociale Geografie 98 (3), 307-324.

Devriendt, L., Burghouwt, G., Derudder, B., de Wit, J., Witlox, F., 2009. Calculating load factors for the transatlantic airline market using supply and demand data -

a note on the identification of gaps in the available airline statistics. Journal of Air Transport Management 15 (6), 337-343. 
Harvey, G., 1987. Airport choice in a multiple airport region. Transport Research 21A (6), 439-449.

Hendricks, K., Piccione, M., Tan, G., 1995. The economics of hubs, the case of monopoly. Review of Economic Studies 62, 83-99.

Kanafani, A., Gosling, G., Thaghave, S., 1975. Studies in the demand for short-haul air

transportation. Special report 127. Institute of Transportation and Traffic Engineering, University of California, Berkeley.

Miller, W.H., 1999. Airlines take to the internet. Industry Week 248 (15), 130-134.

Nero, G., 1999. A note on the competitive advantage of large hub-and-spoke networks. Transportation Research E 35, 225-239.

O'Connor, K., 2003. Global air travel, toward concentration or dispersal? Journal of Transport Geography 11, 83-92.

Oum, T.H., Zhang, A., Zhang, Y., 1995. Airline network rivalry. The Canadian Journal of Economics 28, 836-857.

Pels, E., Nijkamp, P., Rietveld, P., 1997. Substitution and complementarity in aviation, airports vs airlines. Transportation Research E 33 (4), 275-286.

Pels, E., Nijkamp, P., Rietveld, P., 2000. Airport choice in a multiple airport region. Journal of Urban Economics 48, 29-45.

Pels, E., Nijkamp, P., Rietveld, P., 2001. Airport and airline choice in a multiple airport region, an empirical analysis for the San Francisco Bay area. Regional Studies 35, 1-9.

Randall, M., 2007. Drury Lane interchange opens in time for holidays. Times-Herald Record. <www.recordonline.com/apps/pbcs.dll/article?AID=/20071120/NEWS/711200313> (accessed 01.06.09).

Schaafsma, M., 2003. NLS network city and landscape. DISP-Online 154, 28-36.

Shepherd Business Intelligence, 2004. <www.shepsys.com> (accessed 02.12.08).

Starkie, D., 2002. Airport regulation and competition. Journal of Air Transport Management $8,63-72$.

Thompson, M., Caves, R., 1993. The projected market share for a new small airport in the North of England Regional Studies 27 (2), 137-147. 